\title{
Post 2006 Ethio-China Trade Relations: Challenges and Prospects
}

\author{
Getahun Zewde ${ }^{1^{*}}$ \\ ${ }^{1}$ Department of Civics and Ethical Studies, College of Social Science and Humanities, \\ Assosa University, Post Box No: 18, Assosa, Ethiopia.
}

Author's contribution

The sole author designed, analyzed and interpreted and prepared the manuscript.

Article Information

DOI: $10.9734 /$ ARJASS/2017/33141

Editor(s):

(1) Tsung Hung Lee, National Yunlin University of Science \& Technology, University Road, Touliu, Yunlin, Taiwan.

Reviewers:

(1) Ayhan Goktepe, Selcuk University, Konya, Turkey.

(2) Emezi, Charles Nwaneri, Federal Polytechnic Nekede Owerri, Nigeria. Complete Peer review History: http://www.sciencedomain.org/review-history/19124

Original Research Article

Received $31^{\text {st }}$ March 2017

Accepted $20^{\text {th }}$ April 2017

Published $18^{\text {th }}$ May 2017

\begin{abstract}
This article address post 2006 Ethio-China trade relations: Challenges and its prospects. The trade relation between the two countries has shown some improvement after 2006 due to the change of trade policies in Ethiopia, China's growing trade interests in Ethiopia, the strengthened ties between the two governments based on common outlook of the developmental state and the Chinese none intervention policy. After critical analysis of trade data of the two countries, this paper empirically proved that Ethiopia incurs huge deficit in its trade with China. The data reveal that Ethiopia's export to China is much short of its imports from China. Thus, Ethiopia's balance of trade deficit can be largely explained by the unequal terms of trade between agricultural commodities (the country's major export) and capital goods (Ethiopia's major imports from China). In Ethiopia, dependence on the export of few primary agricultural products and raw materials leads to the country's weak export performance and trade deficit. Among others, one of the major challenges of Ethiopia and China trade relations is the balance of trade which is highly slanted in favor of China. The scales are thus already tipped in China's favor making it difficult for Ethiopia to bargain a genuine partnership. The China's stance on Ethiopia is likely to harden in the long run, with more manipulation and exploitation and less benefit for Ethiopia. Also, dumping of low priced export goods forced domestic Ethiopian producers out of business because they cannot compete on price with China. Finally, trade deficit between the two countries can result in lower aggregate demand and therefore slower growth, in the long run it can undermine the standard of living and lead to loss of jobs in home based industries.
\end{abstract}


Keywords: Trade; trade relations; challenges; prospects.

\section{INTRODUCTION}

It is not precisely known when China and Ethiopia first made direct contact in ancient times. Both of them are ancient states of the world; back to around 200 BC. However, the first contact between Ethiopia and China may have been begun around 1000 A.D when China started to import rhinoceros horn from Ethiopia [1]. However, the bilateral trade relations between China and Ethiopia was started in 1956 with limited volume, but after 2005, China has become Ethiopia's largest trading partner and started to take first and at least second place among Ethiopia's trading partners as import and export origin [2].

Following the change of political leadership of Ethiopian People Revolutionary Democratic Front in 1991, the economic policy scene in Ethiopia has undergone fundamental changes. Also the change in the trade policy in turn created favorable ground for nations around the world to see Ethiopia as major trade partner. As a result, Ethiopia is growing trade relations with the People's Republic of China as one of the major [3]. Currently Ethiopia has very good relation with China. Recently, China has stepped into the area of foreign investment, and Ethiopia has to do all which can to take this fresh opportunity to promote investment and trade [4]. However, some scholars see China's economic growth as a positive development model for the third world while others look more critically at China's behavior on the continent and see its parallels to the neo-colonial past [5]. Also, the government of Ethiopia sees the Ethio-China relations as it help to realize the country's development [4].

In fact, as far as economic relations between China and Ethiopia are concerned, the problems related to economic dependency are created due to unequal interactions. For example, the current trade statistics between the two countries show that the average trade exchange (total turnover) from 2006 to 2015 is over 1.6 billion USD per annum out of which 1.4 billion constitutes import from China and the remaining 165 million USD constitute Ethiopia's Export to China which showed an exaggerated trade imbalances between the two countries [4].

Therefore, the trade among the non-equals countries like China and Ethiopia can lead to different adverse outcomes such as the decimation of local industries in Ethiopia. One sided growth in developed countries export without corresponding imports from the developing countries is bound to make the imbalance of trade tilt in favor of developed countries. This is why some people when asked about free trade and the general trade pattern among the developed and the developing countries, said, it is like putting a Rabbit and a Tiger in the same cage.

So, the trade imbalance between the two countries and the exploitative nature of contracting China's firms in Ethiopia has become the major focus of study. The basic purpose of the study was thus filling the gap of trade imbalance and directing possible ways of how such exaggerated negative trade balance can be negotiated in the medium and long term of their relations and to show that Ethiopia should design a trade policy and strategy which is viable to regulate the trade balance and ensure mutual benefit from the trade relations with China. Hence, it is the goal of this paper to study EthioChina trade relations: challenges and prospects. The specific questions which this study seeks to answer are: (1) why is a trade relation between Ethiopia and China growing? (2) What are the major factors that contributed for the trade imbalance between Ethiopia and China? (3) What are the challenges that determine the bilateral trade relations between Ethiopia and China? (4) What are the impacts of trade relations on the Ethiopian economy?

\section{REVIEW OF RELATED LITERATURE}

In both Global Political Economy and International Relations, Critical theorists such as Marxists focus on the structure of the production. From Marxists perspective, market relations are by nature exploitative, and the structure of global capitalism is essentially contradictory since it perpetuates global inequality. Although it may be possible to understand China's involvement in Africa from a Critical perspective, especially since the economic relationship is unequal and some may even view it as exploitative, it poses some analytical difficulties, particularly because China is also part of the Global South and sometimes even espouses the same kind of critical rhetoric against the 'Global North'. In this sense, then Critical Theory is not the most applicable tool to utilize in this study [6]. 
Liberalism in both GPE and IR, views the international system as essentially cooperative, as a result of interdependence. Thus, liberals view the international system as governable through the emergence of regimes, manifested in international regulatory organizations, such as UN. From a liberal perspective, pluralities of actors play equally important role in the international system, and outcomes in international affairs are not only determined by power relations between states, but other factors also play a role [7]. In IR, Liberalism emphasizes morality in international affairs as a way to ensure cooperation and prevent anarchy. Within GPE Liberals view individuals, rather than states, as key economic actors, and firms are seen as important for the creation of wealth. From this perspective the state interference is seen as a distortion of the natural market mechanism, resulting in economic failure [6].

Liberalism, however, is not particularly useful for explaining China's involvement in Africa. For example, although China has become more integrated in to the global market, and thus more interdependent, it has not necessarily led to cooperation. As will be shown, China has repeatedly utilized its position on the UN Security Council to its own advantage, and has not cooperated on issue such as human rights. Furthermore, Liberalism predicts that state intervention leads to market failure. However, this contention does not hold true in the Chinese case, where almost all of China's economic relations are governed by the state, including its economic involvement in Africa. Contrary to liberal contentions, this has not led to economic failure, rather, china's economy has been growing steadily over the last decade and its economic power has strengthened considerably. Therefore China's behavior in the international system and relations with Africa do not easily fit in to the liberal analytical framework [6].

It will be shown, however, that China's involvement in Africa can be well explained from a Realist perspective in International Relation, since it is the theory that most aptly explains China's political stances towards Africa and from the perspective of Political Economy, the theory of Economic Nationalism is most applicable for the explanation and understanding of the political economy of China's involvement in Africa. Thus, due to the structure of international system, states are inherently self-interested entities, with the main aim of building power so as to gain and maintain an advantage in terms of the balance of power [8].
In this sense, China's foreign policy and external behavior "are seen as responsive to the changing dynamics of the international environment," [9]. For example, the concept of 'energy security' is fast gaining prominence as a strategic objective for powerful states. In this context, those states whose behavior can be explained in terms of Realism (such as China) will priorities "securing trade routes and assuring relations with export countries conducive to continuing energy trade" [10].

Furthermore, Realism contends that in order to be politically successful (powerful) states cannot afford to concern themselves with question of morality, and therefore no action should be taken in the name of moralistic principles [8]. For Realists, the most important foreign policy objective is the survival of the state in the international system [9]. Therefore states act rationally toward the achievement of this goal and do not allow issues of morality to impede its attainments.

Realism is, therefore, a useful tool for explaining and analyzing China's foreign policy behavior. For example, the Realist notions of self-interest and moral skepticism help one to understand why China's foreign policies have been described as "generally self-serving and often ruthless. However it is not sufficient to view China's involvement in Africa only through the lens of realism. China's Africa policy challenges some of Realism's main assumption, such as for example the rigid contention that states always place military security above economic security. For this reason it is also necessary to view China's involvement in Africa from the perspective of Economic Nationalism [11].

On the positive side, Chinese manufactured imports might benefit consumers, particularly low income consumers. This is a global phenomenon, since the decline in prices of basic manufactures is a primary factor holding inflation and Chinese products are displacing locally produced commodities. In many countries including Ethiopia, the primary displacement effect is on imports of manufactures from other, and retailers switching their sourcing to cheap Chinese suppliers often with major positive impacts on consumer welfare. For example, in the case of the Ethiopian shoe industry, some of this price decline was due to lower cost imports from China but competition from Chinese manufactures also forced local manufacturers to upgrade their competitiveness [12]. 
Avoidance of double taxation between China and Ethiopia has its own contributions for improvement of Ethio-China trade relations. For instances, in May 2009 the two countries signed an agreement to eliminate double taxation, which is boosting trade and investment. In the new millennium, Ethio-China bilateral ties have registered new progress within the context of FOCAC. The Forum was established by China in 2000 to be held every three years and to strengthen its economic ties with African states including Ethiopia [13]. There are rapidly emerging negative consequences of Chinese trade on developing countries including Ethiopia. For example, in Ghana furniture exporters find it increasingly difficult to compete with Chinese imports, as do South African clothing manufacturers. A similar pattern can be found in the Ethiopian footwear sector [14].

Also in Ethiopia, Chinese firms repeatedly reduced their profit margins to low in the bidding process which undercutting local contractors. Therefore, the challenge for Ethiopian policy makers is to implement strategies that will increase the capacity and competitiveness of local firms and improve local command of the technical dimensions of extractives industries. A principal issue is that competition from Chinese firms in manufacturing construction and retail are crowding out local firms and retailers, even while providing cheaper inputs and services for extractives projects. While financial support from China's government and the tying of loans has given, the Chinese firms have given an unfair advantage over Ethiopian firms. So, Ethiopian firms face capacity constraints even where Chinese investment creates opportunities [15].

In another ways, the variety of loans from China are tied to using Chinese companies and procurement of materials from China and diplomatic conditions, e.g., $70 \%$ construction and civil engineering to be awarded to Chinese companies, which adversely affects wider spillover effects on local economies, job opportunities, and wider knowledge skill transfers. This has underbidding and out bidding effects on local companies because Chinese companies do have $20 \%-25 \%$ and sometimes $40 \%$ of cost reduction when they compete for bid [13].

Ethiopia is losing a lot by trade ties with China and as a result, the balance of payment is extremely unfair which resulted in lack of competitive national companies. The balance of trade is favors China as local industries and merchants have been hit hard by the flood of cheap Chinese wholesale and retail shops used to establish networks to sell goods. The same is true even in Ethiopia producers cannot compete with Chinese companies even in domestic markets since Chinese manufacturers have low production cost and market prices. Therefore, the government should be able to protect infant industries by negotiate to maximize the benefits and minimize the losses in its relation with China [16].

According to Anshan [17] argued Chinese companies are criticized for excessively employing Chinese professionals. With few exceptions, Chinese companies do not also place locals in key managerial posts; they employ locals for the administrative and low paid jobs like clerks, secretaries, guards etc. Some even say these positions are left for the locals because the companies are not allowed to bring their own non skilled employees. This in turn, hampers the local employees from acquiring new technologies and managerial skills. From an economic perspective, it is more efficient and convenient for Chinese entrepreneurs to recruit skilled workers in China than to train local workers.

Also Gedion [13] argued, Most Chinese companies are not intended to transfer technologies to domestic firms. Most of the materials used by Chinese companies are imported from them, which therefore excludes and discourages possible local suppliers. So, it is difficult to say China is a genuine partnership of Ethiopia.

\section{METHODOLOGY}

The study adopted qualitative approaches which used semi-structured interview with key informants to collect data. The study was carried out on the basis of selected respondents from Ethiopian Ministry of Trade and other academician from Addis Ababa University. The semi-structured interview questions were distributed for respondents from Ethiopian Ministry of Trade, National Bank of Ethiopia and other academician from Addis Ababa University.

In this study, both secondary source of data and primary source of data were used. The secondary sources of data taken from different books, articles, research papers and official documents were critically used in order to 
provide readers with general overview about Ethio-China trade relations and its challenges. The primary source of data adopted semistructured interview with key informants' of people working at the Ethiopian Ministry of Trade, National Bank of Ethiopia and some academician from Addis Ababa University to feed the study with recent and updated information about the current performance of Ethio-China trade relations.

The qualitative data entailed through semi structured interview with key informants have been analyzed in the form of discourse analysis and narration, and described qualitatively in sentence form. In addition, secondary data obtained from different documents review was analyzed using descriptive statistical technique, and its results are presented in tabular and graphic forms with due discussions.

\section{RESULTS}

Ethiopia and China had been a long history of trade relations. The two countries trade agreement was signed as long ago as 1996 in order to bolster trade relations, and these have shown progress in its volume from time to time. However, the trade balance was remaining in favor of China until today. For instances, according to the data from Ethiopian Ministry of Foreign Affairs, during 2006-2015, Ethiopia has been importing19,870,132,305.71 USD from China and exported 2,099,056,773.78 USD to
China which shows there was a huge gap between imports and exports which resulted in trade imbalance that favors China. The following figure shows China's share in overall Ethiopia's export and imports.

Even if the volume of Ethiopia's exports to China has increased, the trade imbalance remains a structural problem in Ethiopia trade relations with China. The trade statistics shows that the value of imports from China is growing faster than the receipts from exports to China and thereby giving rise to unbalanced trade relations which results in negative trade balance [18]. The Table 1 shows Ethiopia Export, Import and Trade Balance with China.

Also the Fig. 2 is show Ethiopia Export, Import and Trade Balance with China during 2006-2015.

According to interview made with peoples of Ministry of Trade of Ethiopia, during 2006-2015, Ethiopia's Export to China was less than that of the country's import from China which resulted in negative trade balance and for Ethiopia the benefits from trade might entail pain than gain. So, the governments have a responsibility to find ways of better distributing the gains and mitigating the pain if trade was not to become a source of overall gains to the economy. Moreover, China has been coming in as a donor and Ethiopia as a recipient much as it has been with the west. The trade scales are thus already tipped in China's favor making it difficult for

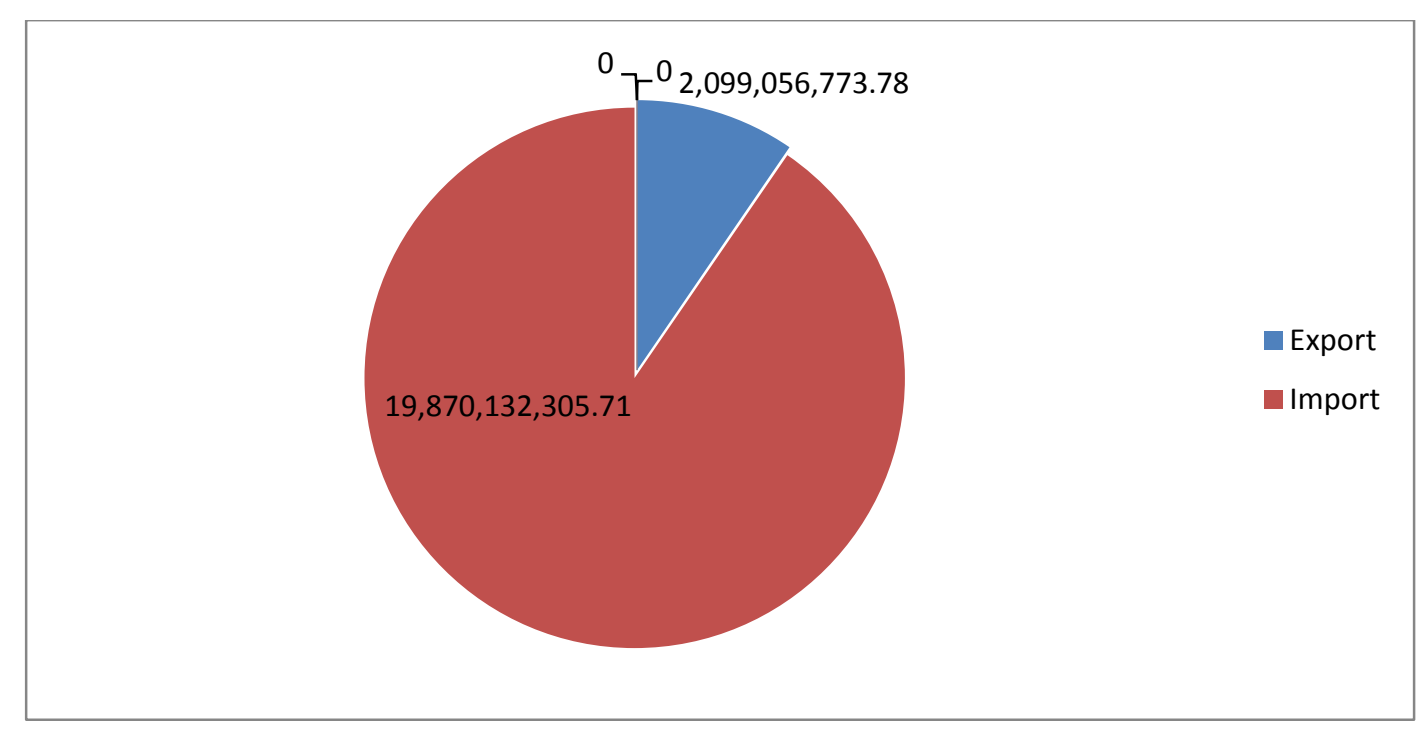

Fig. 1. China's share in overall Ethiopia's export and imports (2006-2015) Source: Ethiopian Ministry of Trade 
Ethiopia to bargain a genuine partnership. While this might be slightly different from the traditional western domination, it is still a form of domination. China's stance on Ethiopia is likely to harden in the long run, with more manipulation and exploitation and less benefit for the country.

The major top ten items which Ethiopia's exporting to China during 2006-2015 include sesame seeds, niobium, tantalum and vanadium ores and concentrates, titanium ores and concentrates, tanned/crust hides /skins of goats or kids in the dry state (crust), tanned /crust skins of goats /kids in the wet state (wet-blue, natural gums, resins, gum-resins, natural oleor'ins /balsams, tanned /crust skins of sheep /lamps in the dry state (crust), oil seeds and oleaginous fruits and oil-cake and other solid residues of rape or colza seeds [18]. The Table 2 shows top ten export items to China.
The major top ten items Ethiopia's importing from China during 2006-2015 includemachines for the reception, conversion and transmission or regeneration of voice, image, parts, other woven fabrics of synch's yarn /non-texted polyester filament, dumpers for off-highway use, new pneumatic tyres of rubber of a kind used on buses or lorries, structures and parts of structures, nes of iron or steel, other primary cells and primary batteries, footwear, not covering the ankle, of rubber or plastics, towers and lattice masts of iron or steel and other machines for the reception conversion and transmission or regeneration [18].

The imports from China in general comprised finished manufactured goods. The recent period's composition of imports from Chinese seems to pose less threat to the development of domestic manufacturing industries and this may

Table 1. Ethiopia export, import and trade balance with china during 2006-2015

\begin{tabular}{llll}
\hline Year & Export & Import & Trade balance \\
\hline 2006 & $78,930,604.60$ & $551,084,760.65$ & $-472,154,156.05$ \\
2007 & $71,687,707.25$ & $663,569,904.96$ & $-591,882,197.71$ \\
2008 & $67,639,544.65$ & $1,019,905,728.03$ & $-952,266,183.38$ \\
2009 & $80,619,516.78$ & $1,688,877,778.90$ & $-1,608,258,262.11$ \\
2010 & $211,120,847.34$ & $1,847,107,585.35$ & $-1,635,986,738.01$ \\
2011 & $228,213,528.45$ & $2,021,717,658.02$ & $-1,793,504,129.56$ \\
2012 & $280,195,080.83$ & $1,673,884,491.95$ & $-1,393,689,411.13$ \\
2013 & $315,862,677.55$ & $2,432,872,032.09$ & $-2,117,009,354.54$ \\
2014 & $308,326,184.98$ & $2,952,993,491.46$ & $-2,644,667,306.49$ \\
2015 & $456,461,081.35$ & $5,018,118,874.30$ & $-4,561,657,793.00$ \\
\hline
\end{tabular}

Source: Ethiopian Ministry of Trade

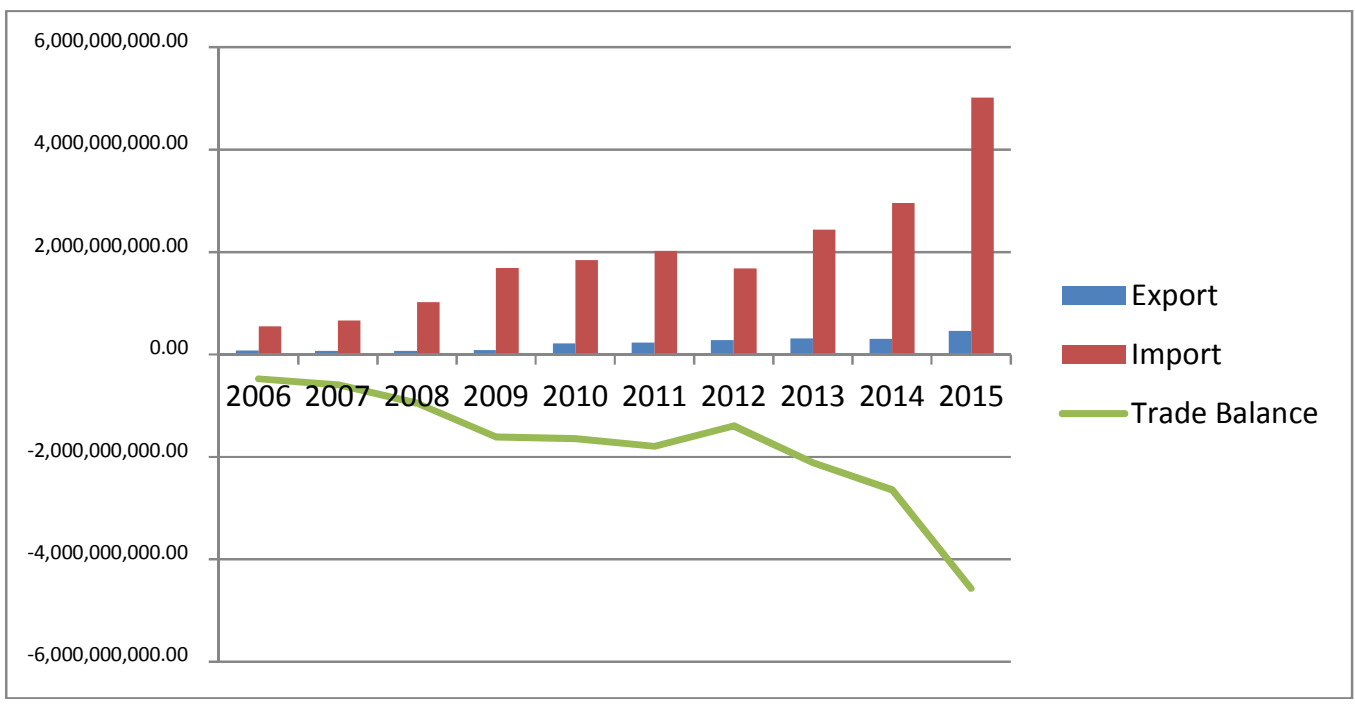

Fig. 2. Ethiopia export, import and trade balance with china during 2006-2015 Source: Ethiopian Ministry of Trade 
severely affected the speed of domestic industries' transition to the production of capital goods in the future, and this can be taken as one of major factor for trade imbalance between Ethiopia and China. The Table 3 shows top ten import items from China.

Furthermore, the flux of Chinese manufactured goods in to Ethiopian markets has resulted in the crippling and sometimes closure of local retailers and manufacturers. According to Amoako [15] Ethiopian firms in retail, construction and manufacturing is crowd out by competitive pressure from Chinese firms and by tying Chinese government loans and investment subsidies that gives Chinese firms unfair advantages over Ethiopian. Ethiopia's textiles and clothing sector are fall the negative impact of Chinese competition, mainly in international markets. For example, textiles and clothing manufacturers lose thousands of jobs because of increased competition. In the retail sector, where Chinese firms have access to cheaper goods, increased competition has put many local out of business.

In addition, it has been noted that about 90 percent of Chinese enterprises in the country are operating targeting local markets. This trend no doubt directly affects local industries and it can be taken as great challenges for Ethiopia. The Chinese trade industries which have been established in Ethiopia will have challenge on the trade and industrial development of the country in the immediate and long run. Because the local industries in the country cannot compete with the Chinese firms products both in terms of volume and variety. In addition, managing the costs will be too difficult to them. The widespread of foreign industries in certain country will allow those industries to dominate the local market, and in the process less quantitative firms of similar infant industry would be pushed out of the market. Particular reference to Chinese investment in Ethiopia, it has been noted that about 90 percent of Chinese enterprises in the country are operating targeting local markets. This trend no doubt directly affects local industries and it can be taken as great challenges for Ethiopia [19].

There are differing arguments regarding the implications of Ethio-China trade relations on Ethiopian economy. Some view China's involvement as an opportunity for Ethiopia's growth and development [20] while others views China's involvement as threat for Ethiopia's growth and development. It has been argued that China is not concerned with neoliberal principle of democracy, good governance and human rights, and therefore attaches no such conditionality to its relations with the country. As consequence, China has been criticized for its part in fuelling conflicts through arms exports to volatile regions and for ignoring human rights

Table 2. Top ten export items to China, 2006- 2015

\begin{tabular}{|c|c|c|c|c|}
\hline Rank & HS code & HS description & Value in USD & Share in (\%) \\
\hline 1 & 12074000 & Sesame seeds & $1,315,409,275.08$ & 85.91 \\
\hline 2 & 41120000 & $\begin{array}{l}\text { Leather prepared after tanning/crusting } \\
\text { include parchment dressed leather }\end{array}$ & $44,049,646.94$ & 2.88 \\
\hline 3 & 26159000 & $\begin{array}{l}\text { Niobium, tantalum and vanadium ores } \\
\text { and concentrates }\end{array}$ & $34,362,148.96$ & 2.24 \\
\hline 4 & 26140000 & Titanium ores and concentrates & $30,020,341.73$ & 1.96 \\
\hline 5 & 41062200 & $\begin{array}{l}\text { Tanned/crust hides/skins of goats or } \\
\text { kids in the dry state (crust) }\end{array}$ & $22,949,655.81$ & 1.50 \\
\hline 6 & 41062100 & $\begin{array}{l}\text { Tanned/crust skins of goats /kids in the } \\
\text { wet state...(wet-blue) }\end{array}$ & $22,047,080.66$ & 1.44 \\
\hline 7 & 13019000 & $\begin{array}{l}\text { Natural gums, resins,gum-resins, } \\
\text { natural oleor'ins /balsams }\end{array}$ & $19,643,350.33$ & 1.28 \\
\hline 8 & 41053000 & $\begin{array}{l}\text { Tanned/crust skins of sheep/lamps..in } \\
\text { the dry state(crust) }\end{array}$ & $18,914,515.26$ & 1.24 \\
\hline 9 & 12079900 & Other oil seeds and oleaginous fruits & $12,096,361.72$ & 0.79 \\
\hline 10 & 23064900 & $\begin{array}{l}\text { Oil-cake and other solid residues of } \\
\text { rape or colza seeds }\end{array}$ & $11,613,268.53$ & 0.76 \\
\hline
\end{tabular}


Table 3. Top ten import items from China, 2006- 2015

\begin{tabular}{|c|c|c|c|c|}
\hline Rank & HS code & HS description & Value in USD & Share in (\%) \\
\hline 1 & 85176200 & $\begin{array}{l}\text { Machines for the reception, conversion } \\
\& \text { transmission or regeneration of voice, } \\
\text { image. }\end{array}$ & $713,768,593.69$ & 19.26 \\
\hline 2 & 85177000 & Parts & $613,267,190.40$ & 16.55 \\
\hline 3 & 54076900 & $\begin{array}{l}\text { Other woven fabrics of synth'c yarn } \\
>=85 \% \text { textrd /non-textrdpolystr filament }\end{array}$ & $544,894,916.45$ & 14.70 \\
\hline 4 & 87041000 & Dumpers for off-highway use & $482,860,579.94$ & 13.03 \\
\hline 5 & 40112000 & $\begin{array}{l}\text { New pneumatic tyres, of rubber of a } \\
\text { kind used on buses or lorries }\end{array}$ & $349,804,956.62$ & 9.44 \\
\hline 6 & 73089090 & $\begin{array}{l}\text { Structures and parts of structures, nes } \\
\text { of iron or steel }\end{array}$ & $271,428,375.17$ & 7.32 \\
\hline 7 & 85068000 & $\begin{array}{l}\text { Other primary cells and primary } \\
\text { batteries, nes }\end{array}$ & $209,386,542.76$ & 5.65 \\
\hline 8 & 64029900 & $\begin{array}{l}\text { Footwear, nes, not covering the ankle, } \\
\text { of rubber or plastics }\end{array}$ & $202,526,817.39$ & 5.46 \\
\hline 9 & 73082000 & Towers and lattice masts of iron or steel & $173,876,797.55$ & 4.69 \\
\hline 10 & 85176900 & $\begin{array}{l}\text { Other machines for the reception } \\
\text { conversion and transmission or } \\
\text { regeneration... }\end{array}$ & $144,533,930.53$ & 3.90 \\
\hline
\end{tabular}

abuses, thereby facilitating instability on Africa in general [21].

In addition, China has been allocated cheap capital to Chinese construction firms in Ethiopia, giving them an unfair advantage over local firms. Thus, China's involvement in Ethiopia may have its own negative implication on Ethiopia economy unless the government gives due attention to the problems.

\section{DISCUSSION}

The goal of this paper is to study post 2006EthioChina trade relations with a view of understanding of its challenges and its prospects. The specific questions which this study seeks to answer were: (1) why is a trade relation between Ethiopia and China growing? (2) What are the major factors that contributed for the trade imbalance between Ethiopia and China? (3) What are the challenges that determine the bilateral trade relations between Ethiopia and China? (4) What are the impacts of trade relations on the Ethiopian economy?

Evidence from this study indicated that there is a huge trade deficit between China and Ethiopia which favoring China. However, there were different factors for growing of trade relations between Ethiopia and China. Among others the main factors that contributed largely to the consolidation of the bonds between Ethio-China trade relations were: the frequent exchange of visits by high level officials and legislators; the successful signing of agreements on a number of significant bilateral trade issues and China's trade policy toward Ethiopia through its "Go Global" policy, and following this policy the trade relations between the two countries have been become strong and the number of Chinese investors in Ethiopia has been increased significantly.

In addition, the common factors which enhanced the bilateral trade relations between Ethiopia and China were; First, China and Ethiopia have been cooperated closely and supporting each other in different domestic and international affairs. Also China-Africa cooperation was another forum which has been strengthened the bilateral relations between Ethiopia and China. Second, Convergence on human rights: putting economic rights over political rights and assigning the highest priority to the right to development was one of the common factors which enhanced the bilateral trade relations of the two countries.

However, trade deficit has been become constant and increased from time to time and Ethiopia could not equally benefit from trade with China. Among others, one of the main reasons for trade deficit between the two countries was that the nature of export-import items of the two countries. Ethiopian exports were highly dominated by primary agricultural commodities 
and raw materials which have been negative implications on Ethiopian trade performance and resulted in trade deficit. For instances, a Sesame seed has been the major Ethiopian exports with the share of $85.91 \%$ from $2006-2015$. But, the expected increase in export revenue from these crops could be invested in the gradual transformation of the sector from being a mere producer of oil seeds to a producer of cosmetics and other final products from oil seeds.

In another ways, primary commodities were vulnerable to price volatility as their prices were determined in world markets and export of primary resources were economically detrimental and can be resulted in trade deficit. In fact under the right conditions, the export of primary products could be create some backward linkages and resulted in negative trade balance. Also Ethiopia imports from China in general, comprised finished manufactured goods. The recent period's composition of imports from Chinese seems to pose less threat to the development of domestic manufacturing industries and this may severely affected the speed of domestic industries' transition to the production of capital goods in the future, and this could be taken as one of major factor for trade imbalance between Ethiopia and China. Also importing manufactured goods has been becomes more serious challenges since Ethiopia pay more birr for these imported materials.

Others factors of trade imbalance between the two countries was underdevelopment of industrial sector in Ethiopia. Many countries including Ethiopia, persuades policies of protectionism to develop national industrial capacity or import substitutions. However, Ethiopia's policies of import substitutions were largely disastrous which faced to challenges like trade imbalance. This could be resulted due to the country paid higher price to commodities which were manufactured or value added than to those that were in their raw form. However, most of the time, negative trade balance was a reflection of the weak nature of the economy of the country and the improvement in trade balance was a result of long term economic transformation of the country. And hence, lack of appropriate infrastructures, inadequate skills levels and lack of good trade policy could be contributed in trade imbalances.

Another challenge was that Ethiopia has been not equally benefited as win-win agreements because, even where markets worked freely,
Ethiopia participates as unequal partners with China. Secondly, where country might have been competitive advantage, the markets were often restricted. In another ways, there were increased competition between China and Ethiopia in third markets, which have been its own challenge on the Ethiopian exports. Also the increased imports from China put competitive pressure on domestic firms and one way they could respond to this is by innovating and moving up the value chain provided they have built the necessary capacity.

Generally, regarding to the implication of the dominance of Chinese trade relations with Ethiopia in the short and long term, the major point was that the perception that China benefits more and Ethiopia less in the short term and long term although the two countries must considered themselves as strategic partners and not to put each other's interests in problems, including trade interests.

\section{CONCLUSION}

The growing trade relation of China's present and potential impact on Ethiopia is both far reaching and complex. However, such a two way relationship can only be fruitful if both parties respect one another and are ready to listen and learn from each other's experience. The relationship also needs to be underpinned by an understanding of how the actions of one are likely to affect the life of the other. Also it is important to achieve greater export diversification by identifying niche markets for Ethiopian manufacturing products in China. Also China should prioritize the development challenges of Ethiopia such as trade imbalances and other problems through enhancing local industries and experience sharing through transforming skill, knowledge and technology.

China's behavior in Africa in general and Ethiopia in particular is seems consistent with realist interpretation of state behavior. It is evident that China is actively seeking to bolster its national power within international arena and support from Ethiopia is crucial to achieving this goal. Furthermore as is consistent with Realist theory, China does not allow moralistic concern to influence the nature of its engagement with Ethiopia. Thus, China will deal with Ethiopian government that it sees as strategic or necessary for achieving its national goals without concern for normative notion such as human rights, transparency, equality and good governance. 
However, problems like trade imbalances could be solved when: the government of Ethiopia focus on being exporter manufactured goods than primary products and encouraged local companies to enhance their capacity; Ethiopian people developed the habits of using local products than using imported Chinese goods; Chinese projects and companies must use locally made inputs rather than depending entirely on their own consumable and nonconsumable products and it is important that projects should be fully agreed upon by Ethiopian government and the governments of China, prior to implementation for win-win effects.

\section{COMPETING INTERESTS}

Author has declared that no competing interests exist.

\section{REFERENCES}

1. Addis D. Relations between Ethiopia and China: An Ethiopian perspective. Addis Ababa, Ethiopia: EIIPD Publisher; 2005.

2. Ethiopian Economics Association. A Survey of the Economic and Trade Relationships between China, India and Ethiopia. Addis Ababa, Ethiopia; 2009.

3. Sharma K, Oliver M. Trade, growth and inequality in the era of globalization. USA and Canada: Routledge, Taylor \& Francis Group; 2008.

4. Ethiopian Ministry of Foreign Affairs. Foreign Affairs and National Security Policy and Strategy Document. Addis Ababa, Ethiopia; 2002.

5. Kaplinsky R, Cormick D, Morris M. The impact of China on Sub Saharan Africa. DFID Agenda setting on economic development; 2006.

6. Brien R, Williams M. Global political economy. Basingstoke: Palgrave; 2003.

7. Nel P. Theories of International Relations. Cape Town: University of Cape Town Press; 1999.

8. Morgenthau $\mathrm{H}$. Politics among nation the struggle for power and peace. New York: Alfred; 1973.

9. Zhao Q. Interpreting Chinese Foreign Policy. Hong Kong: Oxford University Press; 1996.
10. Heller E. The prospect for the power projection for the People's Republic of China. Defense and security analysis. Journal of Foreign Policy. 2003;4:349-367.

11. Roy J, Shweta B. Key issues in trade facilitation. Summary of World Bank. Working Paper. 2005;3703.

12. Morris $M$. The rapid increase of Chinese imports: How do we assess the industrial, labour and socio-economic implications? Paper delivered at the $20^{\text {th }}$ Annual Labour Law Conference, Sandston Convention Centre; 2007.

13. Gedion G. Development assistance from the South: Comparative Analysis of Chinese and Indian to Ethiopia. African Economic Commission; 2014.

14. Tegegne G. Asian imports and coping strategies of medium, small and micro firms. The Case of Footwear Sector in Ethiopia". Chinese Imports \& the Ethiopian Shoe Industry." Journal of Modern African Studies. 2006;4:647-679.

15. Amoako K. What African countries expect from China. African Center for Transformation. 2009;3:23.

16. Tull $M$, Denis $H$. Chinese engagement in Africa: scope, significance and consequence. Journal of Modern African Studies. 2006;3:459-479.

17. Anshan L. China and Africa: Policy and challenges. China Security Review. 2007;3:69-93.

18. Ethiopia Ministry of Trade. Ethiopia and China Trade Statistics Document. Addis Ababa, Ethiopia; 2015.

19. United States International Trade Commission. Sub Saharan Africa: Factors affecting trade patterns of selected industries. Annual Report Investigation. 2008;332-477.

20. Van D, Wath K. Enter the dragon: China's strategic importance and potential for African business. Convergence. 2004;5: 72-75.

21. Taylor I. China's Foreign Policy towards Africa in the 1990s. Modern African Studies. 1998;36:443-460. 


\section{APPENDIX}

\section{Interview Guide line}

The following were semi-structured interview questions prepared for high ranking officials of Ministry of Trade of Ethiopia, National Bank of Ethiopia and Addis Ababa University Key informants.

1. According to the data from Ethiopian Ministry of Trade the ranks of our major trading partner countries have taken a striking different shape, China coming from the bottom to the top. What do you think about the major factors that determine the growth of the post 2005 Ethiopia and China trade relations?

2. Although there has been growth in Ethiopia's overall export performance, the country still maintains serious trade deficit with China. What do you think about the major factors that contributed for deficit between the two countries?

3. What do you think about the challenges and prospects that determine the bilateral trade relations of China and Ethiopia?

4. What do you think about the implications of the dominance of Chinese trade relations with Ethiopia in the medium and long term?

5. Do you think such huge imports would have an impact on the country's economy negative or positive? How?

6. Some scholars argued that Ethiopia and China economic relations are seen as neo colonialism perspectives. What do you think?

7. There has seen great shift in the cooperation (especially in economic areas) from the 'West' to China. What are the major reasons as far as Ethio-China Economic cooperation is concerned?

8. What kind of trade policy that the government must follow to overcome the problems like trade deficit?

\section{List of People Interviewed/ Key Informants}

\begin{tabular}{llll}
\hline Name of people interviewed & Position & Date \\
\hline 1. Professor K. Mathewes & $\begin{array}{l}\text { Professor of Political Science and International } \\
\text { Relations at Addis Ababa University } \\
\text { 2. Dr. Solomon Mebrie }\end{array}$ & $\begin{array}{l}\text { Chair and Assistance Professor in the } \\
\text { department of Political Science and } \\
\text { International Relations at Addis Ababa } \\
\text { University } \\
\text { Directorate of General trade relations and } \\
\text { negotiations (Directorate General) at Ministry } \\
\text { of Trade }\end{array}$ & 3 January 2015 \\
3. Mr. Geremew Ayalewu & $\begin{array}{l}\text { Director of Multi-lateral trade relations and } \\
\text { negotiation directorate at Ministry of Trade }\end{array}$ & 2 February,2015 \\
4. Mr. Lisaneworku Gorfu & Staff member at Ministry of Trade & 14 March, 2015 \\
5. Mr. Badane Abo & Staff member at National Bank of Ethiopia & 14 March, 2015 \\
\hline
\end{tabular}

(C) 2017 Zewde; This is an Open Access article distributed under the terms of the Creative Commons Attribution License (http://creativecommons.org/licenses/by/4.0), which permits unrestricted use, distribution, and reproduction in any medium, provided the original work is properly cited.

Peer-review history:

The peer review history for this paper can be accessed here: http://sciencedomain.org/review-history/19124 